\title{
Erratum to: A 10-year follow up of postmenopausal women with osteoporosis for occurrence of osteoporotic fractures
}

\author{
S. Sunarso • J. Ngo $\cdot$ J. Li-Yu
}

Published online: 1 September 2010

(C) International Osteoporosis Foundation and National Osteoporosis Foundation 2010

Erratum to: Osteoporos Int

DOI 10.1007/s00198-010-1247-9

The names of the second and third authors were inadvertently omitted from poster abstract P668 on page S281 of Osteoporosis International Vol. 21 Supplement 1, May 2010. The title and correct authorship of this abstract are as follows:

A 10-YEAR FOLLOW UP OF POSTMENOPAUSAL WOMEN WITH OSTEOPOROSIS FOR OCCURRENCE OF OSTEOPOROTIC FRACTURES

S. Sunarso ${ }^{1}$, J. Ngo $^{1}$, J. Li- $^{1}{ }^{1}$

${ }^{1}$ University of Santo Tomas Hospital, Manila, Philippines

The online version of the original article can be found at http://dx.doi. org/10.1007/s00198-010-1247-9.

S. Sunarso $(\bowtie) \cdot J$. Ngo $\cdot$ J. Li-Yu

University of Santo Tomas Hospital,

Manila, Philippines

e-mail: samuelsunarso@yahoo.com 